Ciencias Veterinarias
Rev. Ciencias Veterinarias, Vol. 37, Nº 3, [9-10], E-ISSN: 2215-4507 First Symposium on Regenerative Medicine and Nanotechnology, Costa Rica 2019 DOI: https://doi.org/10.15359/rcv.37-3.2

\title{
The horse as a model for translational orthopedic research: examples of studies on the regeneration of cartilage and bone conducted in Costa Rica
}

\section{El caballo como modelo para la investigación ortopédica traslacional: Ejemplos de estudios sobre la regeneración de cartílago y hueso conducidos en Costa Rica}

\author{
Rafael Vindas Bolaños ${ }^{1}$, Jos Malda², René van Weeren³, Janny de Grauw ${ }^{3}$ \\ 1 Cátedra de Cirugía de Especies Mayores, Universidad Nacional, Costa Rica. Email: rafael.vindas.bolanos@una.cr \\ 2 Department of Orthopedics, University Medical Center Utrecht, The Netherlands. Email: j.malda@umcutrecht.nl \\ 3 Department of Equine Sciences, Faculty of Veterinary Medicine, Utrecht University, The Netherlands. Email: \\ r.vanweeren@uu.nl / j.c.degrauw@uu.nl
}

\begin{abstract}
The paper provides results published or to be published of long-term in vivo equine studies to evaluate techniques of possible regenerative matrices of cartilage and bone, by means of cell-free implants or stimulation of the bone marrow. From the fixation techniques analyzed, it can be concluded that the best alternatives are the pressure technique for subchondral defects and a novel hydrogel with selfadhesive capacity for chondral defects.

The equine coxal tuberosity was used for the first time as a model for regeneration studies of bone defects, analyzing scaffolds based on tricalcium phosphate, polymers and nanoparticles, by means of 3-D printing. Osteoconductivity, osteoinductivity, and the importance of microporosity were documented.

Given that decellularized materials do not always give significant desired results in the regeneration of cartilage, it is important to conduct long-term studies. The technique of nanofracture and a novel selfadhesive hydrogel in the knee of the equine showed promising preliminary results in the regeneration of cartilage.

The knee and the coxal tuberosity of the horse represent models of studying cartilage and bone regeneration in a true translational sense as a source of highly valuable information for clinical studies, for both horses and humans.
\end{abstract}

Corresponding Author: rafael.vindas.bolanos@una.cr 
Ciencias

Veterinarias

of
Rev. Ciencias Veterinarias, Vol. 37, Nº 3, [9-10], E-ISSN: 2215-4507

First Symposium on Regenerative Medicine and Nanotechnology, Costa Rica 2019 DOI: https://doi.org/10.15359/rcv.37-3.2

URL: http://www.revistas.una.ac.cr/index.php/veterinaria/index

\section{References}

Mancini I.A.D., Vindas, R.A., Brommer, H., Castilho, M., Ribeiro, A., van Loon, J.P.A.M., Mensinga, A., van Rijen, M.H.P., Malda, J. \& van Weeren, P.R. 2017. Fixation of hydrogel constructs for cartilage repair in the equine model: a challenging issue. Tiss. Eng. Part C. Methods 8(11): 804814. DOI: 10.1089/ten.TEC.2017.0200.

Vindas-Bolaños, R.A., Cokelaere, S.M., Estrada McDermott, J.M., Benders, K., E.M., Gbureck, U., Plomp, S.G.M., Weinans, H., Groll, J., van Weeren, P.R., Malda, J., 2017. The use of cartilage decellularized matrix scaffold for the repair of osteochondral defects: the importance of longterm studies in large animal model. Osteoarthritis and Cartilage 25: 413-420. DOI.org/10.1016/j. joca.2016.08.005

Vindas-Bolaños, R.A. 2019. PhD diss. Cell-free regenerative medicine (RM) strategies for cartilage and bone put to the test in the challenging equine in vivo model. Utrecht University, Netherlands. 